\title{
Conflitos pela água em tempos de seca no Baixo Jaguaribe, Estado do Ceará
}

\author{
GUILHERME REIS PEREIRA I \\ e Miguel DRAGOMIR ZANIC CUELLAR II
}

\section{Introdução}

$\mathrm{M}$

UITO TEMPO antes de se falar em mudanças climáticas, a população do Semiárido tem convivido com períodos de seca prolongada que afetam as atividades agropecuárias e dificultam a melhoria das condições de vida. A região semiárida ocupa uma área de aproximadamente 940 mil $\mathrm{km}^{2}$ abrangendo oito estados do Nordeste e norte de Minas Gerais. Existe 1,7 milhão de estabelecimentos agropecuários, e 89\% são de agricultores familiares numa área equivalente a $43 \%$ do total dos estabelecimentos. A estimativa da população do Semiárido em 2014 é de 23,8 milhões de habitantes, e 38\% residem no meio rural. É na população rural que concentra a maior parcela de habitantes em situação de pobreza e extrema pobreza. Além da necessidade de abastecimento de água para consumo humano, também há demanda para abastecer 31,2 milhões de cabeças de animais, sendo que $53 \%$ do rebanho são bovinos (Insa, 2014).

O problema da escassez de chuva é uma perturbação que se repete e coloca a necessidade de adaptação da população às condições ambientais. A variabilidade climática natural com regime irregular de chuvas é uma característica do Semiárido que precede a chegada dos colonizadores no Brasil, mas que foi registrada na historiografia no final do século XVI durante o processo de colonização. Como a ocupação se deu inicialmente na faixa litorânea, o primeiro registro de seca na História do Brasil aconteceu com a chegada do padre jesuíta Fernão Cardim em 1583. Segundo Cardim, quatro a cinco mil índios fugiram da seca nos sertões indo para o litoral de Pernambuco (Campos, 2014, p.67-8). Houve períodos de seca em 1710-1711, 1723-1729, 1744-1745, 1777-1778, 1808-1809, 18241825, 1835-1837, 1844-1845, 1877-1879, 1982-1883, 1997-1898 (Marengo, 2008). A seca de 1723 a 1729 provocou a morte de escravos dos engenhos de cana-de-açúcar por falta de alimento. O custo com a alimentação dos escravos durante a seca era maior que a aquisição de outros escravos (Campos, 2014, p.68). Em virtude da ocorrência de vários períodos de seca prolongada, que podem se repetir no futuro, as experiências de convivência com a seca servem para analisar de que modo a população reage às situações de escassez de recursos naturais, seja pela aprendizagem e adaptação ou pelo aumento dos conflitos socioambientais. 
O Baixo Jaguaribe também sofreu grandes secas nos anos 1724 até 1728 e em 1732, que mataram muitos habitantes e quase todo o gado. As secas de 1777 a 1778 e de 1790 a 1793 também mataram quase todo o rebanho e acabaram com a indústria do charque jaguaribano (Pantalena; Maia, 2014, p.5). As secas de 1825, 1827 e 1830 foram o marco para o início da construção de açudes para garantir o abastecimento humano e animal. Essa foi a primeira ação para solucionar o problema da seca no Semiárido. Até o final do século XX, tinha-se a ideia de que a seca era uma anormalidade que deveria ser combatida (Rebouças, 1997, p.136). Com a falência desse enfoque, a convivência com o Semiárido passa a nortear as ações de adaptação.

Na memória dos agricultores do Assentamento da Barra do Feijão, localizado no município de Tabuleiro do Norte, a seca de 1957-1958 foi tão intensa quanto à atual. ${ }^{1}$ Como a população vem se adaptando às condições do clima, além de políticas sociais como ampliação da previdência rural, garantia safra, bolsa estiagem e abastecimento de água por caminhões pipa, os impactos da seca não são tão catastróficos como no início do século XX, mas há perda média de $70 \%$ da produção agrícola baseada no manejo tradicional, podendo chegar a $100 \%$ em alguns municípios, e de $30 \%$ do rebanho, de acordo com os dados do IBGE. Com o aquecimento global em curso, a temperatura no planeta tende a aumentar até $4,5{ }^{\circ} \mathrm{C}$ no pior cenário até 2100 , e o Polígono das Secas corre o risco de sofrer um processo de desertificação com a redução das chuvas, aumento da evaporação dos lagos, lagoas, açudes e redução dos reservatórios subterrâneos, provocando a fuga em massa dos flagelados da seca (Marengo, 2008, p.154).

As principais tentativas de solução da escassez de água foram a construção de açudes e barragens após a seca de 1877/1879. Ainda no Império teve início a primeira grande obra hídrica com a construção do açude Cedro, em Quixadá, que foi concluída em 1906 (Pinheiro et al., 2011, p.3). Atualmente a região semiárida conta com 22 mega-açudes com capacidade de 20,3 bilhões de $\mathrm{m}^{3}$ de água (Ribeiro, 2010). Além das ações governamentais, organizações da sociedade civil ligadas à Articulação do Semiárido (ASA) executam o Programa Um Milhão de Cisternas, ${ }^{2}$ com o objetivo de armazenar a água da chuva para o consumo da população rural. Outra ação de adaptação são os projetos de irrigação da fruticultura implantados com recursos do governo federal. $\mathrm{E}$ as cisternas estão destinadas aos pequenos agricultores e os projetos de irrigação beneficiam, em grande parte, as empresas nacionais e multinacionais que ocupam as terras mais férteis das bacias hidrográficas. O agronegócio, baseado na monocultura e especialização das espécies, vai na contramão da resiliência que depende da diversidade da flora e da fauna. Por resiliência entende-se a capacidade social, econômica e do sistema ambiental para lidar com os eventos perigosos, respondendo e se recuperando de modo a manter a função essencial (IPCC, 2014, p.9).

Mesmo em microrregiões onde há açudes e rios perenes, a seca atinge justamente a parcela da população mais vulnerável economicamente que não tem 
acesso aos reservatórios de forma contínua. A questão do manejo e distribuição da água é central para mitigar os efeitos da seca e viabilizar um desenvolvimento mais equitativo. Entretanto, a atuação dos governos na gestão dos recursos hídricos, em geral, e a política de implantação da agricultura irrigada, em particular, têm potencializado os conflitos pela água porque geram uma grande demanda de água e os perímetros irrigados constituem "ilhas verdes" com acesso restrito em meio à vegetação seca.

Nos últimos cinco anos os conflitos pela água no Brasil dobraram e a região Nordeste registrou o maior número em 2013. No tocante aos conflitos contabilizados pela Comissão Pastoral da Terra (CPT), são 37 conflitos de um total de 93 no país. É possível identificar novos focos de conflitos através da imprensa local, não contabilizados pela CPT. O aumento dos conflitos na região semiárida está associado à construção de barragens e à distribuição desigual da água. Aumentou a demanda por água após a implantação de grandes empresas que exploram os recursos naturais com o apoio de investimentos públicos de infraestrutura de irrigação e isenção fiscal (Gonçalves, 2013, p.93). As empresas multinacionais e nacionais se instalaram onde havia oferta de água e os camponeses foram desapropriados nas áreas de implantação dos perímetros irrigados, levando a uma nova concentração fundiária a partir dos anos 1980.

A seca prolongada entre 2012 e 2014 reduziu a disponibilidade de água, agravando as disputas por terras irrigadas e pelo uso da água. O acesso à água é desigual entre as grandes e médias empresas do agronegócio, os pequenos produtores da agricultura familiar e os moradores de cidades em regiões mais secas, principalmente aquelas que eram abastecidas por açudes menores que secaram. Os governos federal, estaduais e municipais, por meio da política de irrigação, promovem um tipo de desenvolvimento desigual e excludente no campo e são causadores de mais conflitos pelos recursos naturais. Em 1996 foi criado o Programa de Apoio e Desenvolvimento da Fruticultura Irrigada do Nordeste de acordo com a filosofia do Banco Mundial que coloca o Estado como indutor das ações privadas na agricultura de irrigação. Em 1998 o governo FHC criou o Programa Polos de Desenvolvimento Integrado do Nordeste voltado para áreas dinâmicas que exportavam (Albano, 2008, p.71).

As primeiras políticas de incentivo à agricultura irrigada no Semiárido ocorreram durante o governo Juscelino Kubitscheck que disponibilizou financiamento aos proprietários para aquisição de motobombas para irrigação nas várzeas dos rios. Na década de 1960, a estratégia da política de irrigação era o combate e redução da pobreza e o foco era a construção dos açudes. Nas fases subsequentes, a partir da criação do Grupo de Estudos Integrados de Irrigação e Desenvolvimento Agrícola (Geida), surge a concepção dos lotes empresariais nos projetos públicos de irrigação através do Programa Nacional para Aproveitamento Racional de Várzeas Irrigáveis (Provárzeas) e do Programa de Financiamento de Equipamentos de Irrigação (Profir). Foi se esboçando uma divisão de 
papéis entre governo e iniciativa privada, onde o governo se restringiu a execução de obras coletivas de uso comum e coube à iniciativa privada a consecução relacionada às atividades produtivas. Em 1995, com o Projeto Novo Modelo de Irrigação, há uma reorientação da política de irrigação visando estimular o agronegócio e o governo assume um papel indutor e regulador (IICA, 2008, p.11-12).

Desse modo, a implantação dos perímetros irrigados nos anos 1990 beneficia as empresas do agronegócio em detrimento das comunidades tradicionais (agricultores, pescadores e ribeirinhos). Com isso, fazem uma reforma agrária às avessas tirando os recursos naturais dos pobres para a apropriação privada do grande capital. O maior esforço do Estado de adaptação ao clima semiárido leva ao aumento da desigualdade no tocante ao acesso e uso da água. Consequentemente, esse tipo de desenvolvimento gera desequilíbrios ambientais. Em 2014, 175 municípios do Ceará estavam em situação de emergência por falta de água. ${ }^{3}$ No contexto de escassez de água, os conflitos latentes se tornam explícitos entre as diferentes classes sociais, particularmente entre os interesses do agronegócio de expansão da produção, a necessidade de sobrevivência dos agricultores e o abastecimento urbano. A modernização capitalista no campo também tem levado a novos conflitos de natureza trabalhista em face do processo de proletarização dos antigos camponeses.

Nos últimos trinta anos ocorreram mudanças na estrutura agrária e nas relações de produção com a implantação do agronegócio irrigado na microrregião do Baixo Jaguaribe. Foi desapropriada uma área de 31 mil hectares no Vale do Jaguaribe, que, numa parte, era utilizada pela agricultura de sequeiro dos pequenos produtores e, na outra, pelo latifúndio. No Perímetro Irrigado de Tabuleiros de Russas, a área desapropriada foi de 18,9 mil hectares, sendo que, na primeira etapa, 5 mil (ha) foram reservados para lotes empresariais, 3,9 mil (ha) foram destinados ao pequeno produtor com lotes de 8 (ha), 1,5 mil para técnico agrícola e agrônomo (Adece, 2011, p.5). A desapropriação de terras de milhares de camponeses tem provocado conflitos como a ocupação do Movimento dos Sem Terra na área do Perímetro Irrigado Jaguaribe/Apodi em função da expropriação e da dificuldade de acesso à água. ${ }^{4}$ Antes disso, em 2009, o DNOCS constatou que cerca de quatro mil hectares do perímetro foram invadidos pelas empresas Del Monte Fresh Produce (1.223,27 ha) e Banesa (356.74 ha) e proprietários médios (DNOCS, 2009). A implantação e gerenciamento dos perímetros irrigados são de responsabilidade do Departamento Nacional de Obras Contra a Seca (DNOCS) que não estabeleceu um diálogo com as comunidades locais quando implantou os perímetros irrigados.

O pequeno produtor reassentado tem que seguir o mesmo padrão tecnológico das empresas. Já na primeira etapa no Perímetro Jaguaribe/Apodi, 81\% de pequenos agricultores que conseguiram um lote no perímetro irrigado foram expropriados em virtude da conjuntura econômica e mudanças da política de ir- 
rigação (Freitas, 2010). Nesse sentido, houve reconcentração de terras e mudança nas relações de produção de modo que a maioria dos pequenos proprietários passou a ser mão de obra assalariada na Chapada do Apodi e Vale do Jaguaribe. Somente o Perímetro Irrigado de Tabuleiros de Russas recebeu R\$ 84 milhões para ampliar a área em 3.600 hectares em 2009. A expansão envolveu desapropriação de 700 famílias de dez comunidades que aguardam desde 2010 o acesso a um lote de terra no perímetro. ${ }^{5}$

Desse modo, a política de desenvolvimento rural no Semiárido, através dos perímetros irrigados, vem favorecendo as empresas nacionais e multinacionais e formando uma massa de trabalhadores assalariados que tem uma renda de 1 a 1,5 salário mínimo, mas deixaram de ser produtor dos seus alimentos. A viabilidade e a expansão do agronegócio dependem de um alto consumo de água. A demanda anual de água para irrigação na bacia do Baixo Jaguaribe corresponde a 103,8 milhões de $\mathrm{m}^{3}$. A distribuição da água do Rio Jaguaribe que era $83 \%$ para irrigação, $12 \%$ para o abastecimento humano e $5 \%$ para o uso industrial, com a necessidade de abastecer a Região Metropolitana de Fortaleza reduziu para $47 \%$ na irrigação, $32 \%$ e $21 \%$ para o consumo humano e industrial. ${ }^{6}$ A baixa escolaridade entre os pequenos produtores e a falta de assistência técnica, por um lado, o manejo inadequado das grandes áreas como inundação e o sistema do pivô central, por outro, levam a uma baixa eficiência no uso da água (Souza et al., 2006, p.3-5). A agricultura irrigada como mecanismo de adaptação ao clima semiárido tende a beneficiar um segmento reduzido da população e sua viabilidade fica ameaçada com um período prolongado de seca que reduz a oferta de água. Diante dessa situação, é possível conciliar as diversas demandas por água em tempos de seca? Como a população reage às perturbações causadas pelas secas prolongadas no que concerne ao manejo e uso da água?

\section{Marco conceitual}

\section{Ecologia politica e conflitos socioambientais}

De acordo com Little (2001, p.107-8), conflitos socioambientais podem ser definidos como disputas entre grupos sociais relacionados aos distintos tipos de relação com seu meio natural. Já o conceito de socioambiental engloba três dimensões: o mundo biofísico, o mundo humano e a relação dinâmica e interdependente entre estes dois mundos. Os conflitos socioambientais podem ser classificados pelo menos em quatro tipos: os conflitos em torno do controle sobre os recursos naturais, os conflitos em torno dos impactos ambientais e sociais provocados pela ação humana e natural, os conflitos em torno do uso dos conhecimentos ambientais. Podemos acrescentar a distribuição de recursos naturais como foco de conflitos que é ampliado num contexto de escassez. Para a Comissão Pastoral da Terra, os conflitos pela água são ações coletivas de resistência para garantir o uso e a preservação das águas e de luta contra a construção de barragens e açudes que desestruturam o modo de vida de comunidades tradicionais, contra a apropriação particular do uso da água no campo (Gonçalves, 2013, p.92). 
A questão dos conflitos ambientais tem sido analisada também pelo campo da Ecologia Política, que trata da interação entre os sistemas sociais e os sistemas naturais no contexto da integração de produtores agrícolas aos mercados regional, nacional e mundial. A origem dessa abordagem se dá nos anos 1960, quando surgiu a percepção da crise ambiental, levando a um debate entre os autores como Ophuls (1977). Tais autores argumentavam que o mundo corria o risco de iminente catástrofe social e ambiental por causa do crescimento da população e era necessário um estado autoritário global para forçar limites de crescimento tanto da população quanto da economia. Não seria possível gerir a crise ecológica no contexto da democracia liberal. Por outro lado, alguns pesquisadores analisaram a relação entre a sociedade e a natureza identificando que os geradores de desequilíbrios ecológicos eram os mecanismos econômicos e políticos da expansão do capitalismo. De acordo com Bryant e Bailey (2005, p.11) a ecologia política surge com o reconhecimento da necessidade de compreender a mudança ambiental pelo seu próprio processo político. Para Blaikie e Brookfield (1987) o campo ecologia política abarca a constante alteração dialética entre sociedade e natureza e entre classes e grupos dentro da sociedade. Esses autores analisaram as formas pelas quais as ações ambientais de posseiros de terras em países do Terceiro Mundo são moldadas pela marginalização econômica, ecológica e política, e pressão por produção. Watts observa que a integração dos posseiros rurais do Terceiro Mundo aos mercados globais sob relações desiguais de poder levam à degradação ambiental. Por outro lado, Blaikie e Brookfield (1987) enfatizam o papel das características biofísicas na criação de gestão variável de tarefas para os posseiros. Watts $(1985$, p.30), ao analisar a desertificação motivada pela seca, constata: "uma forma de desequilíbrio econômico no sistema socioeconômico é transmitida como uma forma de desequilíbrio ecológico" (Watts, 1985 apud Walker, 2005).

Entre os estudiosos da ecologia humana, o conhecimento ecológico e o estilo de vida das comunidades indígenas sobre a natureza passaram a ser cada vez mais valorizados e podem servir de lição na gestão dos recursos naturais pelas sociedades ocidentais. O conhecimento ecológico tradicional é definido como o conhecimento que é adquirido na relação dos seres vivos uns com os outros e com o seu ambiente. O termo tradicional refere-se à transmissão cultural de atitudes sociais, crenças, princípios e práticas adquiridos com a experiência histórica. $\mathrm{O}$ aprendizado é um processo cumulativo e aberto, diferente da visão de rigidez empregada ao termo tradicional em outros contextos (Berkes, 1999, p.5-6). O conhecimento ecológico é o foco da análise sobre a relação entre os sistemas sociais e sistemas naturais a fim de identificar os mecanismos de adaptação às perturbações com vistas ao manejo sustentável dos recursos existentes. A capacidade de adaptação às perturbações na relação entre os sistemas sociais e naturais de forma dinâmica é definida como resiliência. Esse conceito ganha importância no contexto de escassez de recursos ou quando há variabilidade climática com a ocorrência de eventos extremos como secas. 
A questão das mudanças ambientais globais, por se tratar de um problema que é ambiental e social ao mesmo tempo, requer uma compreensão das dinâmicas da relação do sistema social e do sistema natural que se modificam mutuamente. Os cientistas sociais passaram a analisar as causas e efeitos das mudanças ambientais com base no conceito de sistemas socioecológicos. Os sistemas socioecológicos podem ser entendidos como sistemas complexos que possuem atributos como não linearidade, incerteza, variabilidade, escala e auto-organização (Berkes; Folke, 1998 apud Freire, 2009). A ideia de usar o conceito de sistemas socioecológicos é evitar que trate apenas da dimensão social da gestão dos recursos sem considerar a dinâmica do ecossistema. Os sistemas socioecológicos enfatizam a integração entre a sociedade e a natureza e levam em conta as influências recíprocas, conforme argumenta Folke:

\section{Berkes \& Folke started to use the term "social-ecological" system to emphasize the integrated concept of humans in nature and to stress that the delineation between social and ecological systems is artificial and arbitrary. Research sug- gests that social-ecological systems have powerful reciprocal feedbacks and act as complex adaptive systems. (Folke et al., 2005, p.443)}

Segundo Berkes e Turner (2006, p.488) "a auto-organização e adaptação depende de decisões e ações complexas baseado na percepção do status do recurso e vontade de mudar as práticas para ajustar à nova realidade". As sociedades podem ignorar ou responder a crise ambiental ou pequenas perturbações através da diversidade de informações nos sistemas social e ecológico, da aprendizagem a partir da experiência e auto-organização envolvendo múltiplos níveis de tomada de decisão. É o acúmulo de conhecimento ecológico que gera a aprendizagem e adaptação (ibidem, p.489-90).

Berkes e Turner (2006) definem dois mecanismos de produção de conhecimento de conservação: o modelo de crise de esgotamento e o modelo de compreensão ecológica. No modelo de crise de esgotamento os moradores têm que aprender primeiro que os recursos naturais são limitados e só podem aprender esgotando os recursos. Isso ocorreu em algumas ilhas do Pacífico, como a ilha de Páscoa. O modelo de compreensão ecológica coloca relativamente mais peso na elaboração do conhecimento ecológico de um grupo, que conduz a cada vez mais sofisticada compreensão do ecossistema em que eles habitam (ibidem, p.482). Nesse caso, o conhecimento é adquirido em um processo incremental ao longo do tempo.

\section{O conbecimento ecológico dos agricultores no Semiárido}

Os agricultores do Semiárido são mais vulneráveis às condições do clima em razão da natureza de suas atividades produtivas porque dependem do regime de chuva que, quando ocorrem nos padrões normais, duram quatro meses. Eles são dependentes de sua base natural, por isso precisam conhecer melhor os fenômenos da natureza e a propriedade das espécies, sobretudo a adaptação das sementes às condições do clima. Uma das principais formas de tentar reduzir 
a vulnerabilidade dos agricultores do sertão e minimizar as perdas provocadas por períodos de seca tem sido a observação de sinais da natureza para elaborar a previsão do clima para o período do inverno, que é o período das chuvas e também a seleção de sementes crioulas cultivadas no local. Nesse sentido, o conhecimento ecológico tradicional é adquirido observando os sinais da natureza e os resultados das experiências com diferentes espécies de sementes. As técnicas de observação de sinais da flora, da fauna, atmosféricos e datas específicas são conhecidas como experiências de inverno e são passadas de geração para geração. Em uma pesquisa realizada entre agricultores no Seridó Potiguar sobre as experiências de inverno, 77\% afirmaram que conhecem alguma técnica de experiências de inverno, dos quais 63\% acreditam na previsão do clima feita pelos profetas do clima, 50\% alegam que utilizam as previsões para planejar as atividades de produção agrícola. No entanto, além do uso prático das experiências de inverno de previsão para planejar o plantio, prevenir possíveis perdas, também têm uma função subjetiva de criar laços de conhecimento e aprendizagem na relação do homem com a natureza, estudar a natureza e ter esperança de um inverno com boa produção e fartura. As previsões do clima feitas pelos profetas misturam observação objetiva de sinais da natureza com crenças como chuva no dia de São José (Silva, 2013). A religiosidade permeia a relação do sertanejo com a natureza o qual se apoia na fé em Deus para resistir às diversidades e limitações do ambiente em que vive. O imaginário do agricultor sertanejo é típico de uma população tradicional que pode ser definida como um agrupamento de pessoas que se diferenciam do ponto de vista cultural e reproduzem seu modo de vida de forma mais ou menos isolada (Diegues; Arruda, 2001, p.7 apud Silva, 2013).

\section{Metodologia}

Foram utilizadas as imagens do Landsat-8 e Resourcesat para a elaboração de Carta Imagem na resolução 1:10.000 e de mapas hidrológicos dos municípios de Limoeiro do Norte e Tabuleiro do Norte, onde existiam muitas lagoas naturais, afim de identificar os impactos da seca nos corpos d'água. Além disso, foi feito um levantamento de dados estatísticos da produção agrícola em diferentes fontes (IBGE, Secretaria do Comércio Exterior, Funceme e jornais locais). Foram elaborados indicadores sobre produção agrícola, volume de exportação e os mapas do Baixo Jaguaribe para apresentar aos gestores municipais e representantes da sociedade civil. Foi realizada a pesquisa de campo, em setembro de 2014, nos municípios de Tabuleiro do Norte, Limoeiro do Norte e Russas mediante entrevistas com membros do Comitê da Sub-bacia do Baixo Jaguaribe, secretários da agricultura e meio ambiente dos municípios, sindicato dos trabalhadores rurais e agricultores do Assentamento da Barra do Feijão. Verificou-se em que medida a seca provocou queda da produção agrícola na região e as causas e efeitos do desaparecimento das lagoas e açudes. A partir do levantamento dos impactos da seca e participação na reunião do Comitê da Sub-bacia do Baixo Jaguaribe veio à tona a questão dos conflitos pelo uso da água. Neste sentido, os conflitos pela água é um dos impactos sociais da seca dos últimos três anos. 


\section{O caso do Baixo Jaguaribe no Ceará}

No caso do Ceará, a Política de Recursos Hídricos e o Sistema Integrado de Gestão de Recursos Hídricos (Sigerh) foram instituídos em 1992. No ano seguinte foi criada a Companhia de Gestão dos Recursos Hídricos (Cogerh) para realizar a gestão integrada junto com os colegiados criados para permitir a participação da sociedade civil. O Conselho Estadual e os Comitês das Bacias auxiliam na gestão dos recursos hídricos. A partir da definição da Política Estadual de Recursos Hídricos foram obtidos financiamentos do Banco Mundial para a infraestrutura hídrica. A política delineou um modelo institucional descentralizado com o objetivo de possibilitar a participação dos usuários nas decisões sobre a gestão e uso das águas (Pinheiro et al., 2011, p.4-5). Embora os colegiados sejam compostos por diferentes segmentos da sociedade, eles não têm poder de fiscalização e controle da quantidade de água que é utilizada e como é distribuída. Mesmo com a definição da outorga, que autoriza o uso da água em determinada área e a quantidade consumida, como instrumento de controle do uso da água e a cobrança, não há um controle efetivo do uso e ações para diminuição do desperdício. Em muitos casos a área irrigada é maior que a permitida pela outorga e os métodos de irrigação têm baixa eficiência. A plantação de arroz utilizando a inundação da área plantada gera um desperdício significativo de água. Em anos de seca, como em 2014, os produtores de arroz são indenizados pelo governo por não poder plantar em toda área disponível.

Os efeitos da seca podem ser observados através das imagens do satélite Landsat-8, conforme a Figura 1, onde podem ser identificados os polígonos verdes contornados por áreas com vegetação seca. Constata-se o desaparecimento de uma área de $300 \mathrm{~km}^{2}$ coberta por água, entre 2009 e 2014, na microrregião do Baixo Jaguaribe, situada a leste do estado do Ceará. Essa descoberta motivou uma pesquisa de campo naquela região. $\mathrm{O}$ Baixo Jaguaribe é cortado pela bacia do Rio Jaguaribe que tem uma extensão de $610 \mathrm{~km}$, sua área de drenagem chega a $80 \mathrm{mil} \mathrm{km}^{2}$ e é formada à direita pelos rios Carius, Salgado e Figueiredo e, à esquerda, pelos rios Banabuiú e Palhano (Pantalena; Maia, 2014). As chuvas se concentram entre os meses de fevereiro a maio e são distribuídas no espaço de forma irregular. Em condições normais de chuva a partir de $720 \mathrm{~mm}$, havia açudes e muitas lagoas naturais que se formam quando se eleva o nível dos rios e açudes. A disponibilidade de recursos hídricos e o relevo plano possibilitaram a implantação de dois projetos de irrigação na região pelos governos federal e estadual, atraindo empresas nacionais e multinacionais da fruticultura (melão, banana e abacaxi) e de grãos (arroz, feijão, milho e soja).

Apesar da elevação do consumo da água pelas atividades produtivas (agricultura irrigada, mineração e carcinicultura), a região do Baixo Jaguaribe sofre uma das maiores secas das últimas décadas. De acordo com o Gráfico 1, o baixo volume de chuva ocorreu entre 2012 e 2014 . Mesmo com a ocorrência de uma das maiores secas das últimas décadas no Semiárido, os perímetros irrigados têm 
expandido a produção elevando o consumo de água ao mesmo tempo em que os níveis dos reservatórios estão em queda. Num primeiro momento, a seca não impediu a expansão da agricultura irrigada em virtude da construção do açude Castanhão, um dos maiores açudes públicos multiuso com capacidade de 6,7 bilhões de litros. Entretanto, em meados de 2014 começa a ter necessidade de racionamento do consumo de água, comprometendo os planos de expansão da produção para os próximos anos. No Perímetro Irrigado de Tabuleiro de Russas houve a redução de $50 \%$ da água para a lavoura de arroz e $8,5 \%$ para o cultivo de frutas em razão da priorização do abastecimento humano na Região Metropolitana de Fortaleza. Além do crescimento da agricultura irrigada, outra atividade que depende de elevado consumo de água no Vale do Jaguaribe é a carcinicultura.

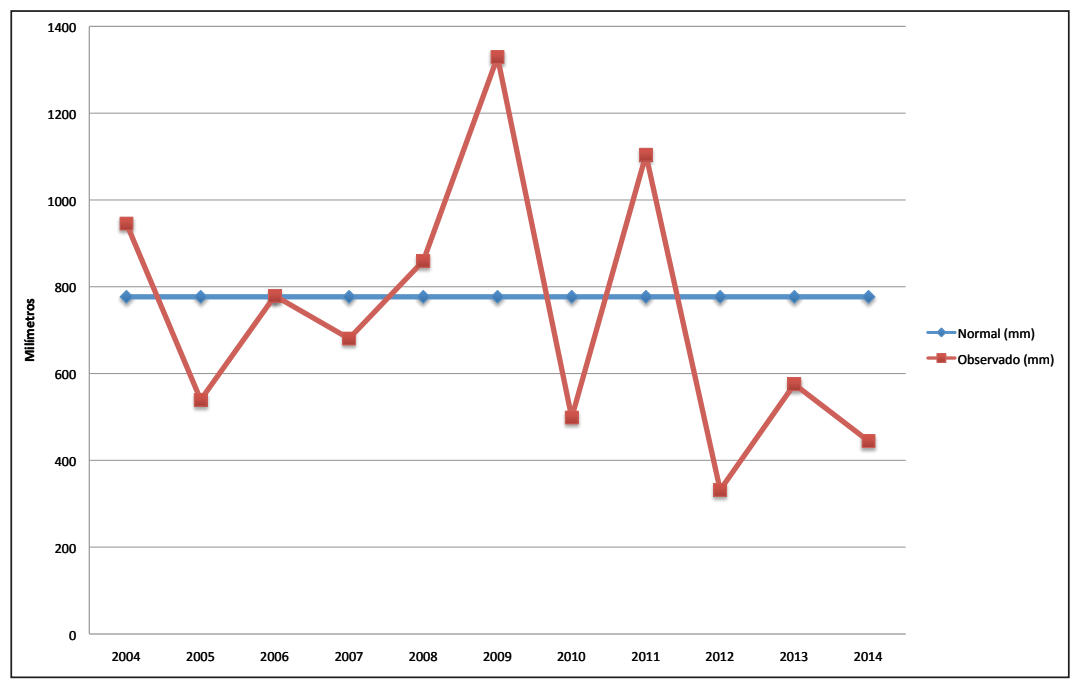

Fonte: Fundação Cearense de Meteorologia e Recursos Hídricos.

Gráfico l - Lâmina anual de chuvas no Baixo Jaguaribe.

Nos últimos dez anos, houve o crescimento da agricultura irrigada com a implantação do Perímetro Irrigado Tabuleiros de Russas, localizado nos municípios de Russas, Limoeiro do Norte e Morada Nova ao longo da margem esquerda do rio Jaguaribe até a confluência com o rio Banabuiú. A partir de 2001, foi implantada irrigação numa área de 10,5 mil hectares, com capacidade para 18,9 mil hectares. O sistema de irrigação é de $50 \%$ por microaspersão e $50 \%$ por gotejamento. $\mathrm{O}$ sistema por microaspersão é feito através de pivô central que resulta na evaporação de parte da água. Os maiores volumes de produção são de frutas (abacaxi, banana, melão, melancia, goiaba, uva) para exportação, seguido do milho, arroz, feijão e soja. Conforme mostra o Gráfico 2, o volume de exportações entre 2001 e 2008 aumentou de US\$ 13 milhões para US\$ 66 milhões. A partir de 2009 houve queda no volume de exportações se mantendo entre US\$ 10 a 14 milhões anuais. 


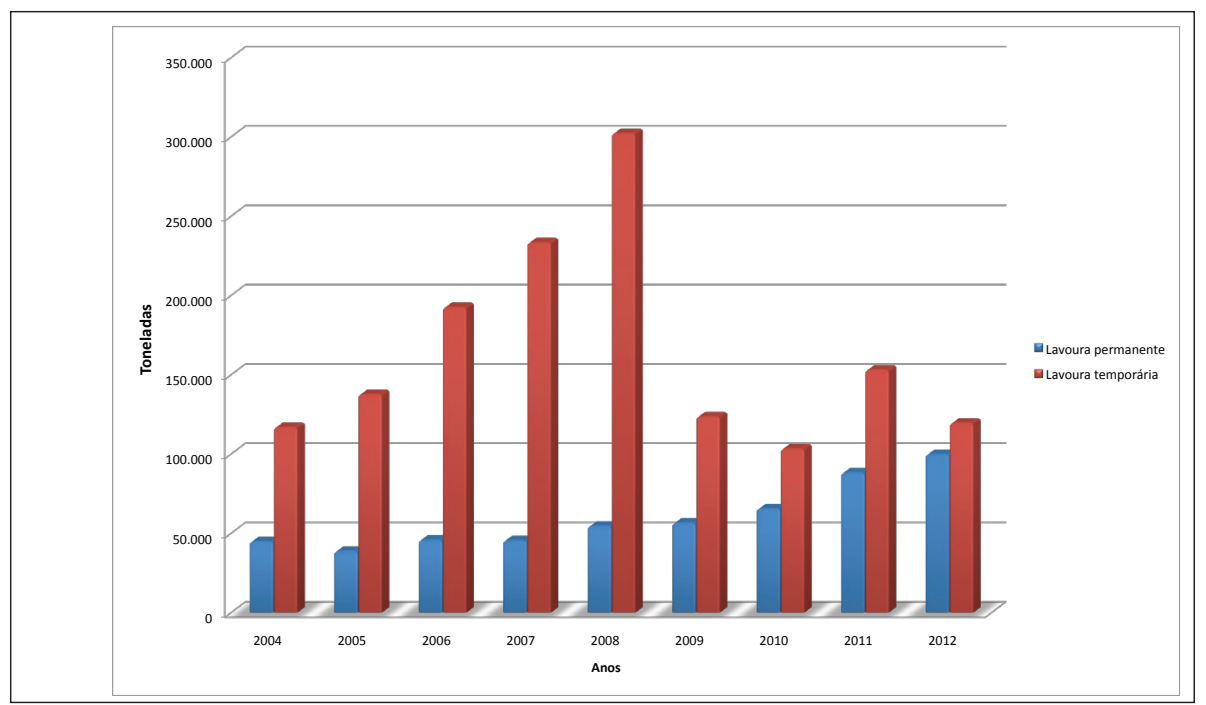

Fonte: Secretaria do Comércio Exterior.

Gráfico 2 - Valores em US\$ da exportação dos municípios Limoeiro do Norte, Tabuleiro do Norte, Quixeré e Russas, no Ceará

A queda nas exportações não pode ser explicada pela ocorrência da seca porque os perímetros irrigados aumentaram a produção no período de seca com a garantia de abastecimento dos açudes. A queda está relacionada à estratégia de mercado das grandes empresas de destinarem parte significativa da produção para o mercado interno. Os efeitos da seca na produção agrícola irrigada estão ocorrendo no terceiro ano de seca. Após a redução do nível dos reservatórios para 30\%, em 2014, é que começou o racionamento, principalmente para o cultivo de arroz que emprega a inundação, gerando desperdício.

Tabela 1 - Impactos da seca de 2012-2014

\begin{tabular}{|c|c|c|c|c|c|c|c|}
\hline Impactos & Unidade de medida & 2009 & 2010 & 2011 & 2012 & 2013 & 2014 \\
\hline $\begin{array}{l}\text { Pluviosidade média } \\
\text { de } 720 \mathrm{~mm} \text { obser- } \\
\text { vado em mm }\end{array}$ & $\begin{array}{l}\text { Volume de chuva } \\
\text { observado em mm }\end{array}$ & 1329,5 & 498,6 & 1104,3 & 331,7 & 575,4 & 444,3 \\
\hline Ambiental & $\begin{array}{l}\text { Área de corpos } \\
\text { d'água em } \mathrm{Km}^{2}\end{array}$ & 309,9 & & 310,5 & 106,1 & 92,5 & 16,9 \\
\hline Econômico & $\begin{array}{l}\text { Valor Bruto da } \\
\text { Produção Perímetro } \\
\text { Irrigado de Tabu- } \\
\text { leiro de Russas em } \\
\text { milhões R\$ }\end{array}$ & 36,4 & 33,8 & 53,8 & 59,9 & 97,9 & \\
\hline Econômico & $\begin{array}{l}\text { Produção de Limoeiro } \\
\text { do Norte (mil t.) }\end{array}$ & & & 85,3 & 108,5 & 117,9 & 116,5 \\
\hline Social & $\begin{array}{l}\text { Famílias desapro- } \\
\text { priadas }\end{array}$ & 700 & & & & & \\
\hline
\end{tabular}

Fonte: Elaboração própria a partir da pesquisa de campo. 


\section{Agricultura familiar}

A agricultura familiar baseada em lavouras temporárias como o milho, o feijão e a mandioca sofreu uma perda que varia de $70 \%$ a $80 \%$ da produção. ${ }^{7}$ A variação climática tem efeitos diretos na agricultura de sequeiro e pode ser verificado na variação da produção da lavoura temporária, conforme o Gráfico 3 . Houve aumento nos anos que teve chuva acima da média $(720 \mathrm{~mm})$ e cai a partir de 2009, mantendo-se baixa até 2012. Apesar da queda da produção, a área colhida em 2009 e 2011 foi maior que em 2008, indicando queda de produtividade. Considerando que os dois perímetros irrigados do Baixo Jaguaribe aumentaram a produção mesmo com a seca, pode-se inferir que a queda de produção refere-se à agricultura familiar. Os dados mostram que o acesso desigual à água gera situações completamente distintas entre os produtores que estão instalados nos perímetros irrigados e os pequenos agricultores sem acesso à irrigação. Enquanto a produção do Perímetro Irrigado de Tabuleiros de Russas triplicou nos últimos cinco anos, a agricultura familiar teve queda de $70 \%$ por causa da maior seca dos últimos cinquenta anos.

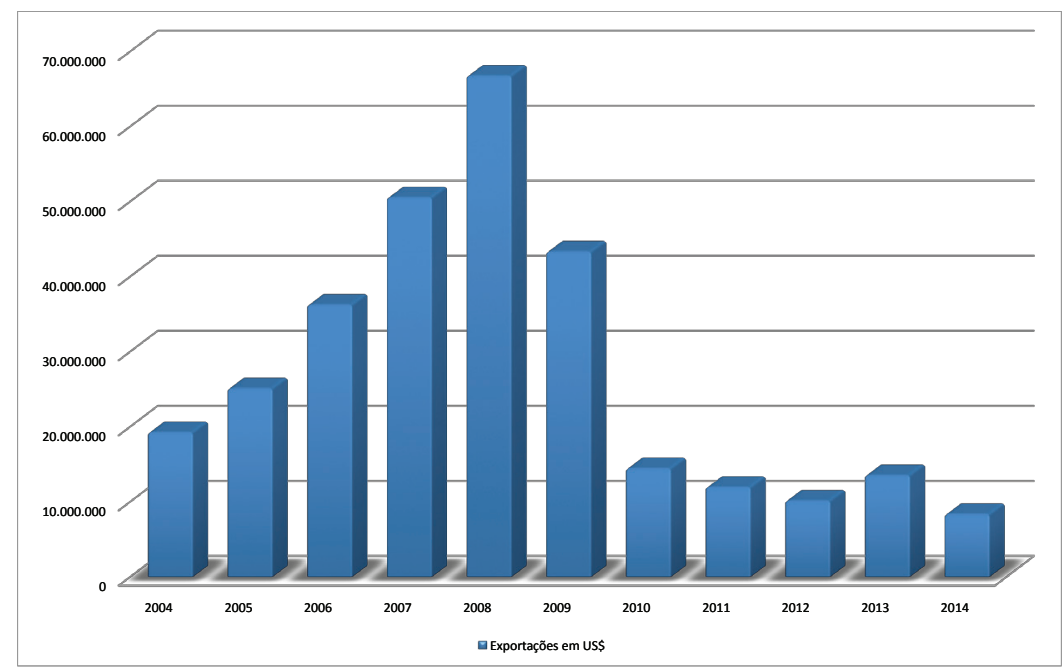

Fonte: IBGE/Sidra.

Gráfico 3 - Produção das lavouras permanente e temporária do Baixo Jaguaribe.

\section{Impactos ambientais}

A implantação do agronegócio nos perímetros irrigados provocou mudanças ambientais significativas com desmatamento, contaminação da água do subsolo por causa do uso dos agrotóxicos e o surgimento de ilhas verdes em meio à paisagem seca própria da Caatinga. Com base nas imagens dos satélites Landsat-8 e Resourcesat, constata-se que a seca que assola o Semiárido desde 2012 resultou no desaparecimento de dezenas de lagoas, entre as quais a lagoa da Salina, lagoa do Meio, lagoa do Lima, lagoa do Itapuio, lagoa do Saco do Barro e redução de açudes nos municípios de Tabuleiro do Norte e Limoeiro do 
Norte, conforme mostram os mapas hidrológicos na Figura 2. As lagoas estão localizadas numa área de drenagem de $4.970 \mathrm{~km}^{2}$ da bacia Jaguaribe e se formavam com a elevação do volume de água da bacia. Os vales sofrem enchentes em períodos que há volume de chuva acima do normal. Nos anos de seca as lagoas deixaram de receber água do rio Jaguaribe que teve o volume reduzido em função da seca e da retenção de água pelo açude Castanhão a fim de abastecer a Região Metropolitana de Fortaleza. As lagoas secaram principalmente devido à evaporação. De acordo com a medição do software Spring, a área com superfície de água que era de $310,5 \mathrm{Km}^{2} \mathrm{em} \mathrm{2011}$, foi reduzida para $16,9 \mathrm{~km}^{2} \mathrm{em} 2014$. A imagem de 2012 na Figura lb mostra que o Perímetro Irrigado Jaguaribe/Apodi e as margens dos rios Banabuiú e Jaguaribe são as únicas áreas verdes porque são irrigadas contrastando com a vegetação seca.

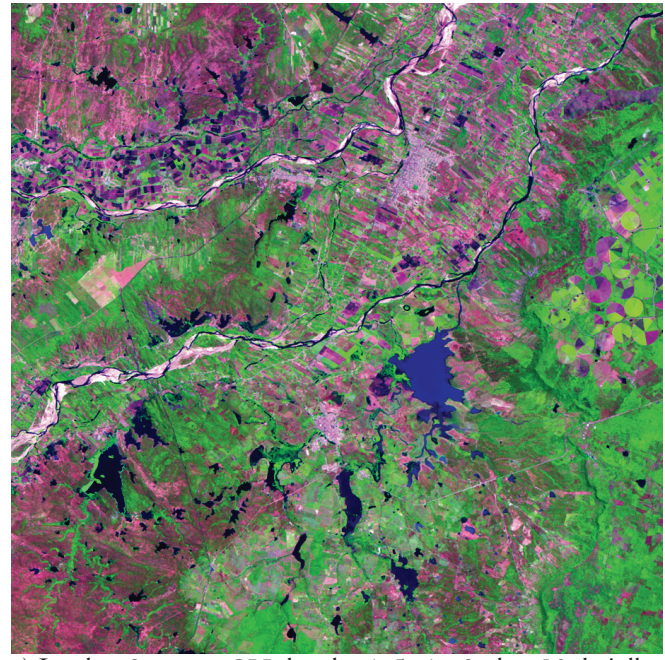

a) Landsat-8, sensor OLI, bandas 4, 5, 6 e 8, data 13 de julho de $2009(216 / 64)$.

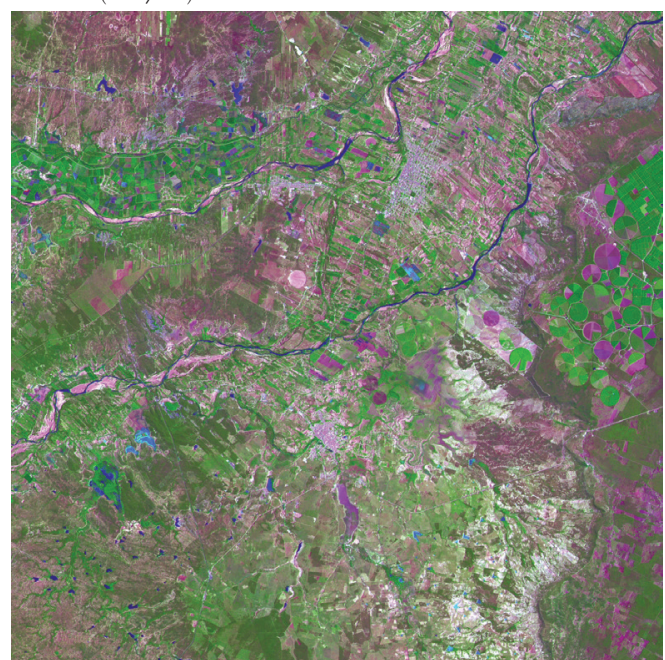

c) Landsat-8, sensor OLI, bandas 4, 5, 6 e 8, data 10 de julho de $2013(216 / 64)$

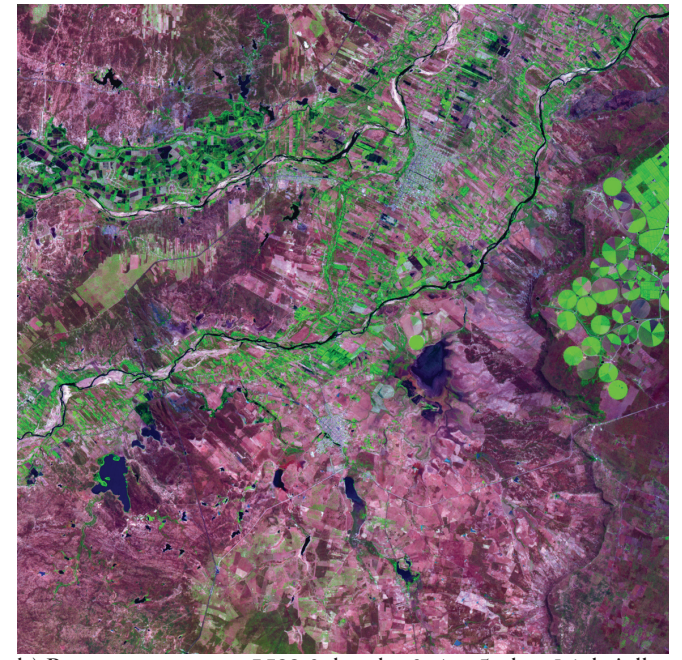

b) Resourcesat, sensor LISS-3, bandas 3, 4, e 5, data 16 de julho de $2012(335 / 79)$.

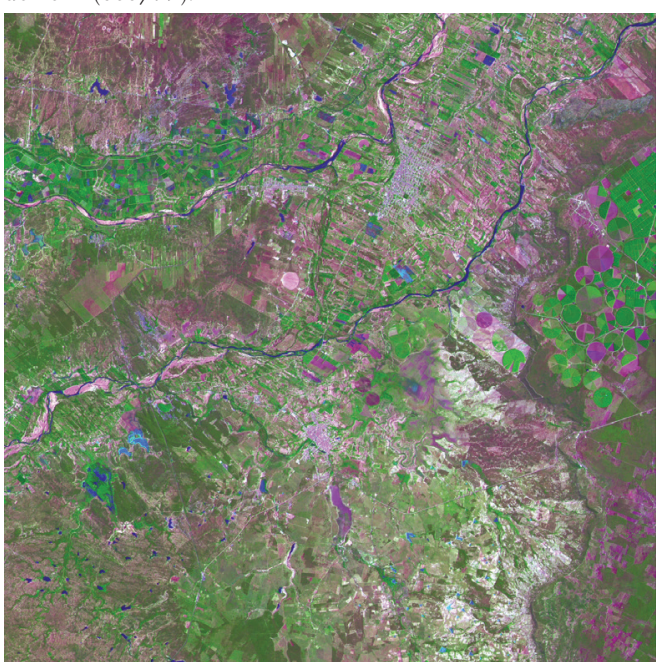

d) Landsat-8, sensor OLI, bandas 4, 5, 6 e 8, data 26 de maio de $2014(216 / 64)$

Figura 1 - Imagens Landsat-8 e Resourcesat dos municípios de Limoeiro do Norte e Tabuleiro do Norte em 2009, 2012, 2013 e 2014. 

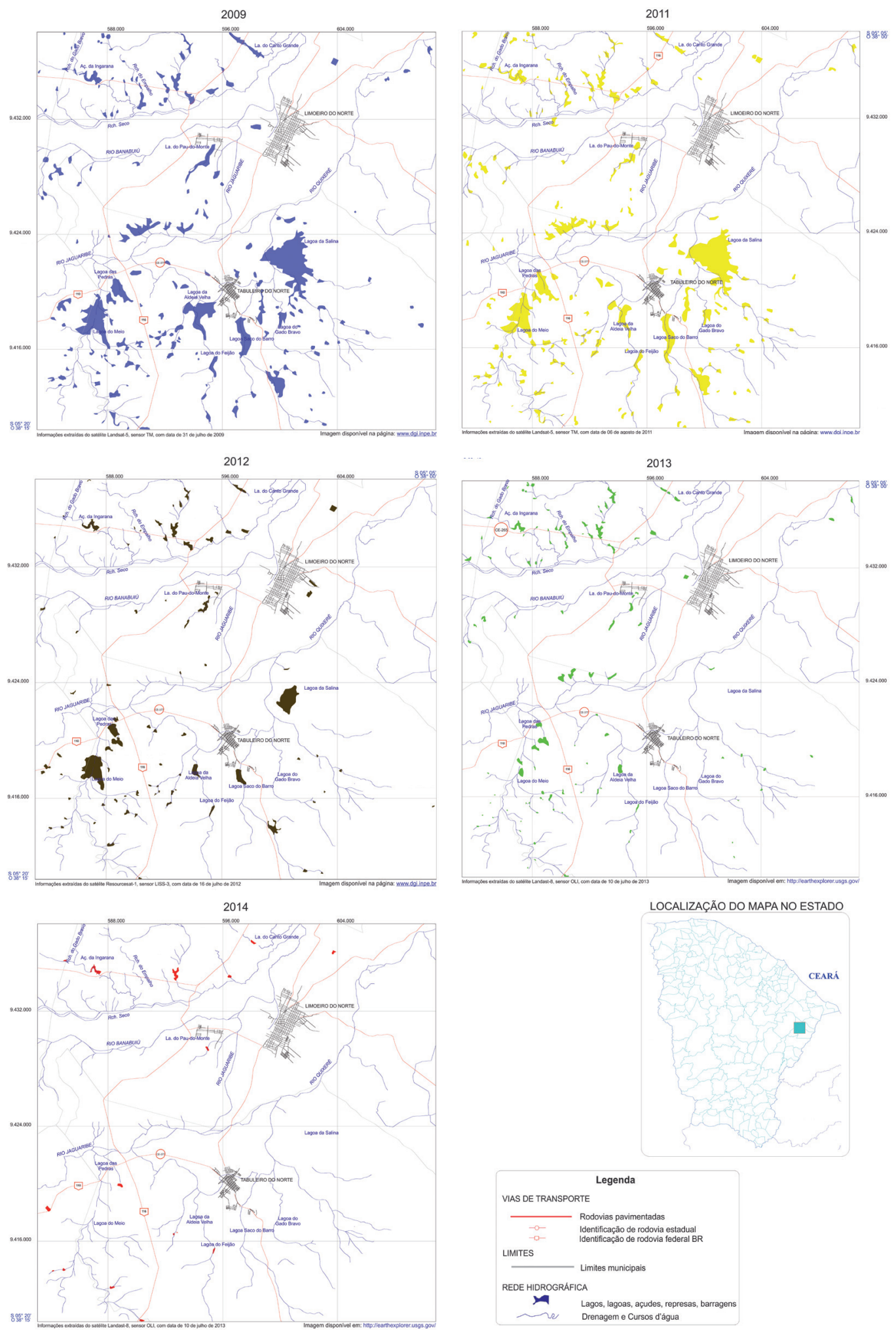

LOCALIZAÇĂO DO MAPANO ESTADO

Fonte: Elaboração própria.

Figura 2 - Mapas hidrológicos do Baixo Jaguaribe entre 2009 e 2014. 
A partir de 1999 começou o cultivo de arroz irrigado entre a lagoa da Salina e o rio Jaguaribe. Com isso, a lagoa passou a ser assoreada para irrigar o arrozal. Naquele ano o valor da produção de arroz irrigado foi de 1,4 milhão de reais, a preços de 2000. A implantação do arrozal no local levou à criação de um movimento social em defesa da lagoa da Salina em 2000, liderada pelo secretário do Meio Ambiente Jesus Moreira. ${ }^{8}$ Em 2008, quando houve chuva acima da média para a região, houve a contaminação da água da lagoa e do rio Jaguaribe por causa dos agrotóxicos utilizados na lavoura, provocando a morte dos peixes. Atualmente a água do rio é bombeada para inundar uma área de cerca de 400 hectares para o plantio do arroz e pode-se observar através da imagem de satélite que há lavoura onde havia a lagoa da Salina.

Vale ressaltar que, além do impacto ambiental da seca no ambiente aquático e sua cadeia alimentar, há também os efeitos sociais e econômicos. As comunidades rurais que vivem próximas às lagoas e açudes se beneficiavam desses recursos para dessedentar o gado, irrigar a lavoura de sorgo e pescar. De acordo com o secretário de desenvolvimento rural de Tabuleiro do Norte, alguns moradores chegavam a pescar entre 20 e $30 \mathrm{~kg}$ de peixe por semana nas lagoas e açudes. No assentamento da Barra do Feijão os moradores pescavam no açude que tinha $4 \mathrm{~km}$ de extensão, em setembro de $2014 \mathrm{o}$ açude estava praticamente seco.

A seca está provocando mudanças ambientais no Baixo Jaguaribe. Além do desaparecimento das lagoas, há uma migração dos produtores da Chapada do Apodi, que utilizavam poços artesianos para irrigação, que atualmente estão esvaziados, para as margens do rio Jaguaribe fazendo o arrendamento das terras ou se instalando nos perímetro irrigados. As empresas e agricultores estão descendo para o vale do rio Jaguaribe porque baixou o nível do aquífero Jandaíra a ponto de não poder mais bombear águas dos poços perfurados. Em 2009, a Del Monte expandiu a produção de frutas na região se instalando no Perímetro Irrigado Jaguaribe/Apodi para cultivar bananas. A multinacional já produzia abacaxi em Limoeiro do Norte e melão em Quixeré. Com isso, o número de empregos diretos chegou a cinco mil. Contudo, a empresa tem enfrentado greves devido às precárias condições de trabalho, excesso de horas extras, problema de intoxicação dos trabalhadores e ocupações. De acordo com o representante do Perímetro Irrigado Jaguaribe/Apodi, a Del Monte abandonou área que produzia melão por causa do fim da isenção fiscal e a ocupação do MST. ${ }^{9}$

\section{Conflitos pela água}

Considerando que a escassez de água no Semiárido é um problema recorrente, existe um histórico de conflitos pelo acesso à água das bacias hidrográficas. Tentou-se solucionar o problema aumentando a oferta de água mediante a construção de açudes que retêm as águas dos rios. Contudo, a demanda por água tem crescido principalmente por causa da expansão da agricultura irrigada. Além disso, três anos consecutivos de seca provocaram a redução dos reservatórios. 
Há a tentativa de racionalizar o uso dos recursos hídricos através de um arcabouço institucional que tem como principal mediadora a Companhia de Gestão dos Recursos Hídricos (Cogerh), mas os conflitos tendem a aumentar na medida em que a situação se agrava e comunidades deixam de ser abastecidas pelos açudes. Pinheiro (2002) definiu uma tipologia dos conflitos de usos da água segundo duração, partes envolvidas, área de abrangência, objeto, descrição, instância, instrumento legal referenciado, impacto ambiental, instituições envolvidas na mediação. Em vários casos há um desrespeito da legislação por parte de proprietários de terras que fazem barramentos e canais clandestinos para inundar grandes áreas, reduzindo o escoamento da água do rio. No caso dos Açudes Thomaz Osterne e Manuel Balbino situados no Vale do Rio Carás, no Ceará, o conflito envolvendo os usuários, a justiça e os órgãos do Sistema de Gestão de Recursos Hídricos durou mais de cinco anos. Os usuários de Juazeiro do Norte denunciaram os barramentos irregulares aos órgãos públicos (Pinheiro et al., 2011). No município de Limoeiro do Norte, agricultores abandonaram suas terras e invadiram uma área federal onde há um duto que liga o rio Jaguaribe a plantações de soja, banana e milho. Os agricultores alegam que não têm condições de sobreviver em suas terras sem água. Por outro lado, os produtores do ponto de irrigação fazem ameaças no caso de faltar água para irrigar as lavouras. De acordo com o presidente da Associação Rural dos Produtores da Chapada do Apodi: "Se isso acontecesse, aí sim teria um conflito. Seria difícil segurar produtores para não invadir o acampamento à bala vendo as plantações morrendo". ${ }^{10}$

Os moradores do Vale do Jaguaribe têm dificuldades de acesso à água, como os do município de Jaguaribara, que foram atingidos pela construção do Castanhão e reassentados próximos ao Canal do Trabalhador, mas são impedidos de utilizar a água para abastecer o gado. O canal é monitorado por câmeras e a polícia é acionada caso os moradores utilizem a água. Há casos em que o agricultor teve que dar água da torneira para o gado, aumentando a conta 700 vezes (Lins, 2008). Algumas comunidades do município de Morada Nova deixaram de ser abastecidas pelo açude Cipoada porque o volume de água foi reduzido para $20 \%$ da capacidade. Os moradores ameaçaram arrombar o Canal da Integração caso não seja aberta uma válvula para liberar água para o riacho Santa Rosa. O Canal de Integração liga o açude Castanhão ao Pecém para abastecer Fortaleza. Os agricultores argumentam que já não tem água nem pastagem para o rebanho, a plantação que não vingou, além da morte dos peixes. ${ }^{11}$

Alguns produtores e moradores do Baixo Jaguaribe acusam o desperdício de água na Região Metropolitana, no entanto, a agricultura irrigada e, sobretudo, a cultura do arroz gera alto consumo de água em função da inundação da área de plantio. Assim, o sistema de irrigação tem baixa eficiência (Souza et al., 2006) e não há um controle efetivo do volume de água utilizado em toda a área plantada o que leva à distribuição desigual da água entre as diferentes classes sociais. 
Com a situação de risco de colapso por causa da escassez de água provocada pela continuidade da seca, os conflitos pela água se tornam mais evidentes. Há dificuldade de controle da quantidade de água utilizada na agricultura irrigada, sobretudo das propriedades próximas aos rios. De acordo com os membros do Comitê da Sub-bacia do Baixo Jaguaribe, os produtores conseguem uma outorga para plantar em uma determinada área, mas plantam em área maior consumindo mais água que o permitido. Além disso, há uma migração dos produtores da Chapada do Apodi para as margens do rio Jaguaribe, o que dificulta o controle do consumo na agricultura irrigada e o risco de contaminação da água devido ao uso intensivo de agrotóxicos. Por outro lado, algumas comunidades rurais e cidades são abastecidas com caminhão-pipa por determinação da justiça. A distribuição e o acesso à água são desiguais entre os médios e grandes produtores e as comunidades rurais da agricultura familiar na região. Além disso, o governo estadual tem priorizado o abastecimento da Região Metropolitana e agricultores do Baixo Jaguaribe estão com dificuldades de ter acesso à água porque os açudes mais próximos secaram. Em 20 de outubro de 2014, alguns agricultores de Limoeiro do Norte protestaram instalando um curral com animais em frente à Cogerh para reivindicar a transposição de água do rio Jaguaribe para o açude Carrapicho para manter perenizado um braço do rio Banabuiú. ${ }^{12}$

O representante do Perímetro Irrigado Jaguaribe/Apodi no Comitê da Sub-bacia do Baixo Jaguaribe argumenta que há quebra de compromisso por parte do governo estadual que havia garantido o abastecimento de água para a produção agrícola. As empresas se instalaram nos perímetros irrigados em virtude da disponibilidade de água. Ele alega que há desperdício do consumo de água na Região Metropolitana de Fortaleza e o racionamento nos perímetros irrigados pode gerar desemprego. O Secretário de Agricultura de Russas teme um colapso na produção do Perímetro Irrigado do Tabuleiro de Russas por causa da redução do volume de água do açude Castanhão que está com $30 \%$ da sua capacidade em setembro de 2014.

Há desperdício no consumo de água em Fortaleza, as pessoas nos apartamentos abrem a torneira à vontade sem saber a situação dos reservatórios. Um banho que deveria gastar 50 litros acaba gastando 500 litros. O governo do estado precisa conscientizar a população para não desperdiçar a água que vai daqui pra lá. (secretário de Agricultura de Russas, setembro de 2014)

No discurso dos entrevistados do Baixo Jaguaribe, a população da Região Metropolitana de Fortaleza desperdiça a água que passa pelo território deles. Também há uma indignação quando falta água em cidades próximas do açude Castanhão, enquanto o abastecimento dos perímetros irrigados é garantido. A falta de abastecimento em alguns municípios do Ceará como Jaguaretama, que foi atingido pela construção do açude Castanhão cuja água abastece os perímetros irrigados e o Porto Industrial do Pecém em Fortaleza. No início de 2015 
houve mobilização de entidades da sociedade civil de Jaguaretama para reivindicar a construção de uma adutora para garantir o abastecimento de água. ${ }^{13}$

O desperdício da agricultura irrigada através da inundação e da dispersão não é, no entanto, considerado com a mesma gravidade que o desperdício na Região Metropolitana de Fortaleza. Na situação de crise ambiental as diferentes classes sociais no Baixo Jaguaribe procuram se mobilizar para ter acesso à água aumentando o número de conflitos e reivindicações. Isso quer dizer que a reação à situação de escassez que prevalece é de cobrança dos órgãos públicos responsáveis pela gestão dos recursos sem adotar uma prática mais racional e eficiente do uso da água. As experiências recorrentes de falta de água não têm levado a uma mudança de comportamento da maior parte da população no sentido de economizar um recurso natural que é limitado e pode se tornar escasso com secas prolongadas.

\section{Considerações finais}

A modernização da agricultura no Semiárido com a implantação do agronegócio da fruticultura irrigada e inserção no mercado mundial resultou no aumento do uso dos recursos hídricos que são escassos nessa região. Nesse processo de modernização capitalista do campo, explicita-se o conflito no tocante à distribuição e uso da água. Além de ser tratada como um bem público, a água passa a ser vista como um bem econômico. Houve uma tentativa por parte de empresas de estabelecer um valor econômico para água a fim de lucrar com o serviço de saneamento básico. A tentativa de privatização dos serviços públicos segue o modelo do Banco Mundial que financiou obras de infraestrutura hídrica no Ceará. A lei estabelece que a prioridade do uso da água seja para o abastecimento humano, muitos municípios do estado do Ceará, e também em outros estados do Nordeste, distantes de açudes, dependem de distribuição por meio de caminhões-pipa que são insuficientes. A má distribuição, combinada com a redução da oferta de água, impõe o desafio para a Gogerh e o governo estadual de mediação dos conflitos. Mesmo tendo um modelo de gestão que prevê a participação dos usuários nas decisões em comitês, as relações de poder desiguais entre os usuários dificultam o atendimento da população economicamente mais vulnerável do mesmo modo que o agronegócio tem sido atendido em tempos de escassez.

Entre os impactos da seca, pode-se destacar o surgimento de conflitos socioambientais em razão da escassez de água, mesmo numa região privilegiada do Semiárido com a presença de rios perenes e os açudes Orós e Castanhão. Pode-se observar nas imagens de satélite que há polígonos verdes em meio à paisagem seca da Caatinga. Existem conflitos pelo acesso à água entre as empresas instaladas nos perímetros irrigados e os pequenos agricultores distantes dos recursos hídricos. Também há conflito entre o abastecimento humano na Região Metropolitana de Fortaleza e a agricultura irrigada próximo à Bacia do Jaguaribe. Do lado do agronegócio, há o interesse em continuar aumentando 
a produção e, consequentemente, aumentando o consumo de água. Por outro lado, na Região Metropolitana de Fortaleza há mais de dois milhões de pessoas que são abastecidas, em grande parte, pelos açudes Orós e Castanhão através do Canal do Trabalhador. Há conflito com o Movimento dos Trabalhadores sem Terra que ocuparam as terras de empresas dentro do perímetro irrigado. As mesmas terras que tinham sido invadidas por empresas. Grandes obras de infraestrutura hídrica e a integração de bacias têm garantido o abastecimento, mas há o risco de colapso e aumento das disputas caso a seca continue assolando a região.

A situação atual é comparável ao modelo de crise de esgotamento de Berkes e Turner (2006) no qual os moradores têm que aprender primeiro que os recursos naturais são limitados e só podem aprender esgotando os recursos. No entanto, situações de escassez já ocorreram em outros períodos de seca, mesmo assim tanto produtores quanto a população urbana, principalmente da Região Metropolitana de Fortaleza, não aprenderam que há necessidade de se fazer o uso mais eficiente dos recursos hídricos. Somente quando a falta de água se torna concreta é que a população se vê obrigada a economizar o pouco de água disponível sob pena de não tê-la.

\section{Notas}

1 Dados obtidos por meio de pesquisa a respeito da percepção dos agricultores sobre as mudanças climáticas no referido assentamento em setembro de 2014.

2 A cisterna é uma tecnologia social para a captação de água da chuva e armazenamento. Com capacidade para 16 mil litros de água, a cisterna supre a necessidade de consumo de uma família de cinco pessoas por um período de estiagem de oito meses.

3 Tempo seco castiga agricultores do CE, que ficam sem água até para beber. Disponível em: <http://gl.globo.com/economia/agronegocios/noticia/2014/09/tempo-seco-castiga-agricultores-do-ce-que-ficam-sem-agua-ate-para-beber.html>. Acesso em: 30 set. 2014.

4 MST fecha canal do Perímetro Irrigado Jaguaribe/Apodi em Limoeiro. Disponível em: <http://limoeiroplantaopolicial.blogspot.com.br/2014/05/mst-fecha-canal-do-perimetro-irrigado.html>. Acesso em: 17 set. 2014.

5 Russas News. Dossiê aponta impactos dos perímetros irrigados no $\mathrm{CE}, 1^{\circ}$ de julho de 2014. Disponível em: <http://russasnews.com.br/destaque/dossie-aponta-impactos-dos-perimetros-irrigados-no-ce/>. Acesso em: 15 set. 2014.

6 A cultura do arroz adota o sistema de irrigação por inundação, consumindo o valor volume entre as culturas. O sistema de cobrança da água em vigor leva em consideração a área irrigada e não o volume de água aplicado. Com isso, a inundação ou o sistema de gotejamento tem o mesmo custo. O arroz ocupa o dobro da área recomendável, cerca de dois mil hectares no município de Morada Nova.

7 A estimativa da perda foi informada pelo Secretário de Desenvolvimento Rural de Tabuleiro do Norte.

8 Informação levantada por meio de entrevista com o Secretário do Meio Ambiente de Tabuleiro do Norte em setembro de 2014. 
9 As informações foram obtidas em reunião com membros do Comitê da Sub-bacia do Baixo Jaguaribe em 5 de setembro de 2014.

10 Folha de S.Paulo. Disputa pelo acesso à água envolve até jagunços no interior do Ceará. Disponível em: <http://wwwl folha.uol.com.br/cotidiano/2014/09/1517676-disputa-por-acesso-a-agua-envolve-ate-jaguncos-no-interior-do-ceara.shtml $>$. Acesso em: 18 set. 2014 .

11 Diário do Nordeste. Famílias ameaçam arrombar trecho do Canal da Integração. 17 de maio de 2012. Acesso em: 15 out. 2014.

12 Diário do Nordeste. Protesto: Agricultores fazem curral em frente à Cogerh em Limoeiro do Norte. Disponível em: <http://blogs.diariodonordeste.com.br/valedojaguaribe/>. Acesso em: 4 nov. 2014.

13 Movimento dos Atingidos por Barragens (MAB). Jaguaretama tem sede: População se mobiliza contra falta d'água em município cearence. Publicado em 2.2.2015. Disponível em: <http://www.mabnacional.org.br/noticia/jaguaretama-tem-sede>. Acesso em: 28 abr. 2015 .

\section{Referências}

AGÊNCIA DE DESENVOLVIMENTO DO ESTADO DO CEARÁ (ADECE). Perímetros Públicos Irrigados do Ceará, 2011. Disponível em: < file:///C:/Documents\%20 and\%20Settings/teste/Meus\%20documentos/Downloads/perimetros_publicos_do_ ceara_sb\%20(2).pdf>.

ALBANO, G. P.; SÁ, A. J. Políticas públicas e globalização da agricultura no Vale do Açu-RN. Revista de Geografia, Recife, v.25, n.2, maio/ago. 2008.

BERKES, F. Sacred ecology: traditional ecological knowledge and resource management. Philadelphia: Taylor \& Francis, 1999.

BERKES, F.; FOLKE, C. Linking social and ecological systems. In: BERKES, F.; FOLKE, C.; COLDING, J. (Ed.) Linking social and ecological systems: management practices and social mechanisms for building resilience. Cambridge: Cambridge University Press, 1998.

BERKES, F.; TURNER, N. Knowledge, Learning and the Evolution of Conservation Practice for Social-Ecological System Resilience. Human Ecology, v.34, n.4, August 2006.

BLAIKIE, P.; BROOKFIELD, H. (Ed.) Land degradation and society. London; New York: Methuen, 1987.

BRYANT, R.; BAILEY, S. Third world political ecology: an introduction. s. 1.: Taylor and Francis E-Library, 2005.

BRYANT, R. Power, knowledge and political ecology in the third world: a review. Progress in physical geography, 1998. Disponível em: <ppg.sagepub.com>.

CAMPOS, J. N. B. Secas e políticas públicas no semiárido: ideias, pensadores e períodos. Estud. Av. [online], v.28, n.82, p.65-88, 2014.

CARNEIRO, F. F.; RIGOTTO, R. M.; PIGNATI, W. Frutas, cereais e carne do Sul: agrotóxicos e conflitos ambientais no agronegócio no Brasil. e-cadernos CES, v.17, p. 10-30, 2012. 
CEDEPLAR/UFMG; FIOCRUZ. Mudanças climáticas, migrações e saúde: cenários para o Nordeste Brasileiro, 2000-2050. 2008

DEPARTAMENTO NACIONAL DE OBRAS CONTRA AS SECAS - DENOCS. Levantamento agroeconômico social do Perímetro Irrigado Jaguaribe-Apodi. Fortaleza-CE, 2009. (Relatório Técnico).

DOSSIÊ PERÍMETRO IRRIGADO. Perímetro Irrigado Jaguaribe-Apodi: Invasão de Terras, Precarização do Trabalho, Contaminação por Agrotóxico e Violência no Campo, 2014.

FOLKE, C. et al. Adaptive Governance of Social-Ecological Systems. Annu. Rev. Environ. Resour, v.30, p.441-73, 2005.

FREIRE, R. Sustentabilidade de sistemas socioecológicos sob a lente da resiliência: o caso de uma associação agroecológica na Amazônia ocidental. 2009. Tese (Doutorado) Universidade Estadual de Campinas. Campinas, 2009.

FREITAS, B. M. C. Marcas da modernização da agricultura no território do Perímetro Irrigado Jaguaribe-Apodi: uma face da atual reestruturação socioespacial do Ceará. 2010. 181f. Dissertação (Mestrado em Geografia) - Universidade Estadual do Ceará. Fortaleza, 2010.

GONÇALVES, A. Água e a sede do capital em conflitos no campo - Brasil 2013 Coordenação: Antônio Canuto, Cássia Regina da Silva Luz, Flávio Lazzarin. Goiânia: CPT Nacional - Brasil, 2013.

GUIMARÃES, R. P.; FONTOURA, Y. S. R. Natureza ético-política das dimensões humanas das mudanças ambientais globais. Revista da ANPEGE. v.6, p.73-87, jan./ dez. 2010.

INSTITUTO INTERAMERICANO DE COOPERAÇÃO PARA A AGRICULTURA (IICA). A irrigação no Brasil: situação e diretrizes / Ministério da Integração Nacional - Brasília: IICA, 2008.

INSTITUTO NACIONAL DO SEMIÁRIDO (INSA). Boletim Informativo. Ano II, n.11, 24 a 30 de agosto de 2014 .

INTERGOVERNMENTAL PANEL ON CLIMATE CHANGE - IPCC WGII AR5 Climate Change 2014: Impacts, Adaptation, and Vulnerability. Summary for Policymakers, 2014.

LACERDA, N.; OLIVEIRA, T. Agricultura irrigada e a qualidade de vida dos agricultores em perímetros do Estado do Ceará, Brasil. Revista Ciência Agronômica, Fortaleza, v.38, n.2, p.216-23, 2007.

LINS, C. Os impactos territoriais e socioeconômicos do Canal da (Des) Integração no Ceará no contexto do Médio e Baixo Jaguaribe. 2008. Dissertação (Mestrado) - Universidade Federal do Ceará. Fortaleza, 2008.

LITTLE, P. Os conflitos socioambientais: um campo de estudo e de ação política. In: BURSZTYN, M. (Org.) A difícil sustentabilidade: política energética e conflitos ambientais. Rio de Janeiro: Garamond, 2001.

LITTLE, P. E. Ecologia política como etnografia: um guia teórico e metodológico. Horizontes Antropológicos, Porto Alegre, ano 12, n.25, p.85-103, jan./jun. 2006.

MARENGO, J. A. Vulnerabilidade, impactos e adaptação à mudança do clima no semi- 
árido do Brasil em Mudança do Clima no Brasil: vulnerabilidade, impactos e adaptação. Parcerias Estratégicas, Brasília, DF, n.27, p.149-76, dez. 2008.

OPHULS, W. Ecology and the politics of scarcity. San Francisco: Freeman \& Company, 1977.

PANTALENA, A. F.; MAIA, L. P. Marcas da ação antrópica na história ambiental do Rio Jaguaribe, Ceará, Brasil. Revista da Gestão Costeira Integrada, 2014.

PAINEL BRASILEIRO DE MUDANÇAS CLIMÁTICAS - Impactos, Vulnerabilidades e Adaptação. Contribuição do Grupo de Trabalho 2 ao Primeiro Relatório de Avaliação Nacional do Painel Brasileiro de Mudanças Climáticas, Brasília, DF, 2013.

PINHEIRO, M. I. T. Tipologia de conflitos de usos das águas: Estudos de casos no estado do Ceará. 2002. Dissertação (Mestrado) - Universidade Federal do Ceará. Fortaleza, 2002.

PINHEIRO, M. I. T.; CAMPOS, J. N. B.; STUDART, T. M. de C. Conflitos por águas e alocação negociada: o caso do vale dos Carás no Ceará. Rev. Adm. Pública, Rio de Janeiro, v.45, n.6, Dec. 2011. Disponível em: <http://www.scielo.br/scielo. php?script=sci_arttext\&pid=S0034-76122011000600003\&lng=en\&nrm $=$ iso $>$. Acesso em: 30 set. 2014.

REBOUÇAS, A. da C. Água na região Nordeste: desperdício e escassez. Estudos Avançados, São Paulo, v.11, n.29, p.127-54, 1997.

RIBEIRO, M. B. Rede de açudes do Nordeste a maior do planeta Terra. Revista Cidadania é Meio Ambiente, 2010. Disponível em: <http://www.ecodebate.com. br $/ 2010 / 03 / 28 /$ rede-de-acudes-do-nordeste-a-maior-do-planeta-terra-artigo-de-manoel-bomfim-ribeiro/>. Acesso em: 23 abr. 2015.

SILVA, N. M. Experiências de inverno no Seridó Potiguar. 2013. Dissertação (Mestrado) - Universidade Federal do Rio Grande do Norte. Natal, 2013.

SOUZA, F.; BARBOSA, F. C.; TEIXEIRA, A. S.; COSTA, R. N. T. Eficiência de irrigação em perímetros irrigados do estado do Ceará, Brasil, México, 2006.

SOUZA, F. et al. Racionamento atinge pelo menos 7 perímetros irrigados, Jornal de Hoje. 13.8.2014. Disponível em: <http://www.opovo.com.br/app/opovo/cotidiano/2014/08/13/noticiasjornalcotidiano,3297203/racionamento-atinge-pelo-menos-7-perimetros-irrigados.shtml>. Acesso em: 16 set. 2014.

TURNER, M. D. Overstocking the range: a critical analysis of the environmental science of Sahelian pastoralism. Economic Geography, n.69, p.402-21, 1993.

WALKER, P. Ecologia política: onde está a ecologia? Progress in Human Geography, v.29, n.1, p.73-82, 2005.

WATTS, M. J. Silent violence: food, famine and peasantry in northern Nigeria. Berkeley, CA: University of California Press, 1983.

Social theory and environmental degradation: the case of Sudano-Sahelian West Africa. In: GRADUS, Y. (Ed.) Desert development: man and technology in sparselands. Dordrecht: D. Reidel, 1985. 
RESUMO - Este trabalho analisa os impactos ambientais e socioeconômicos da seca de 2012 a 2014 na microrregião do Baixo Jaguaribe do estado do Ceará, com o objetivo de compreender como a população reage à crise ambiental, seja pela aprendizagem e auto-organização a partir da experiência de escassez, seja pelo aumento dos conflitos por acesso à água. Verifica-se que houve o desaparecimento de lagoas e açudes equivalente a uma área de $300 \mathrm{~km}^{2}$, entre 2009 e 2014, em dois municípios da região. Ademais, pode-se destacar o surgimento de conflitos socioambientais em razão da escassez de água, mesmo em um dos territórios mais privilegiados do Semiárido com a presença de rios, lagoas e açudes. Há conflitos associados ao acesso e distribuição da água entre as empresas dos perímetros irrigados, os pequenos agricultores, a Região Metropolitana de Fortaleza, a população de municípios da região e o Movimento dos Trabalhadores Rurais sem Terra (MST).

PALAVRAS-CHAVE: Impactos, Seca, Conflitos socioambientais, Política de recursos hídricos.

ABSTRACT - This paper analyzes the environmental and socioeconomic impacts of drought from 2012 to 2014 in the Lower Jaguaribe in the Ceará State with the goal of understanding how the population reacts to the environmental crisis, whether through self-organization and learning from the experience of scarcity either by increasing conflicts over access to water. We note that there was the disappearance of lakes and reservoirs equivalent to an area of $300 \mathrm{~km}^{2}$ between 2009 and 2014 in two counties. Moreover, we can highlight the emergence of environmental conflicts because of water shortages, even in one of the most privileged areas of the semiarid region with the presence of perennial rivers, lakes and dams. There are conflicts associated with access and distribution of water among companies in irrigated perimeters conflicts, small farmers, the Metropolitan Region of Fortaleza and the Movement of Landless Workers.

KEYWORDS: Impacts, Drought, Socio-environmental conflicts, Water resources policy.

Guilherme Reis Pereira é analista em Ciência e Tecnologia no Instituto Nacional de Pesquisas Espaciais (Inpe), Natal (RN). @-guilherme@crn.inpe.br

Miguel Dragomir Zanic Cuellar é engenheiro eletrônico com especialização em Sensoriamento Remoto e Geoprocessamento, trabalhando atualmente no Instituto Nacional de Pesquisas Espaciais (Inpe), Natal (RN). @-miguel@crn.inpe.br

Recebido em 15.4.2015 e aprovado em 22.5.2015.

${ }^{\text {I }}{ }^{\text {II }}$ Instituto Nacional de Pesquisas Espaciais. Natal/RN, Brasil. 
